\title{
Xanthogranulomatous salpingo-oophoritis: a case report and review of literature
}

\author{
Keval A. Patel, Kinalee P. Chothani, Bimal Patel, Dhaneshwar N. Lanjewar*
}

Department of Pathology, Gujarat Adani Institute of Medical Sciences, Bhuj, Gujarat, India

Received: 11 August 2020

Accepted: 15 September 2020

\section{*Correspondence:}

Dr. Dhaneshwar. N. Lanjewar,

E-mail: dnlanewar2011@gmail.com

Copyright: (C) the author(s), publisher and licensee Medip Academy. This is an open-access article distributed under the terms of the Creative Commons Attribution Non-Commercial License, which permits unrestricted non-commercial use, distribution, and reproduction in any medium, provided the original work is properly cited.

\begin{abstract}
Xanthogranulomatous inflammation of ovary is a rare disease that is characterized by presence of large number of lipid laden macrophages with an admixture of neutrophils, lymphocytes, plasma cells and multinucleated giant cells. It is misdiagnosed as ovarian tumour that leads to extensive surgery including hysterectomy. In this report we describe a case of Xanthogranulomatous salpingo-oophoritis along with review of literature.
\end{abstract}

Keywords: Oophoritis, Salpingitis, Xanthogranulomatous inflammation.

\section{INTRODUCTION}

Xanthogranulomatous inflammation is a chronic inflammation that destroys the affected organs. Inflammation is commonly described in kidney, gallbladder, stomach, urinary bladder, bones, testis and epididymis. ${ }^{1,2}$ Xanthogranulomatous inflammation of the female genital tract is rare and mainly limited to ovary, fallopian tube and endometrium. ${ }^{3,4,5}$ Clinically patients present with fever, pain and fullness in lower abdomen. In this report we describe a case of unilateral xanthogranulomatous salpingo-oophoritis, which presented as tubo-ovarian mass.

\section{CASE REPORT}

A 25 year old female (P2L2) presented with fullness of lower abdomen and abdominal pain for 10 days duration. Her history revealed that she is having in situ intrauterine contraceptive device (IUCD). The ultrasonography of abdomen and pelvis showed a well defined hypoechoic solid mass in left adnexa measuring $7 \times 5 \mathrm{~cm}$, which was on the abdominopelvic MRI showed hyperintense irregular, solid tuboovarian mass. The left ovary was indiscernible from the mass, while right ovary and fallopian tube was normal and uterus showed in situ intrauterine contraceptive device in lower segment. Hematological investigation showed haemoglobin of 8.0 gm $\%$, total leucocyte count of $12,000 / \mathrm{mm}^{3}$, ESR 26 $\mathrm{mm} / \mathrm{hr}$, liver function tests and renal function tests were within normal limits. On exploratory laparotomy the left tuboovarian mass was found to be adherent to urinary bladder, anterior wall of uterus and bowel, resected tuboovarian mass was received for histopathological evaluation. The specimen of left tubo-ovarian mass measured $6 \times 4.8 \times 2.5 \mathrm{~cm}$ and weighed $25 \mathrm{gm}$. The external surface of it was irregular and showed attached fallopian tube. The cut surface of tubo-ovarian mass was solid and was yellowish in colour and showed areas of necrosis (Figure 1A). Microscopic examination revealed diffuse infiltration of ovarian tissue by sheets of foamy histiocytes with abundant lipid laden vacuoles in their cytoplasm and inflammatory cells comprising of lymphocytes, plasma cells and polymorphs (Figure 1B). Histology of fallopian tube also showed presence of xanthogranulomatous inflammation. On Immunohistochemistry foamy macrophages showed diffuse cytoplasmic positivity for CD 68 (Figure 1C), confirming a diagnosis of xanthogranulomatous salpingo-oophoritis. Periodic acid Schiff stain, gram stain and acid-fast stains were negative for microorganism. Bacterial culture of tubo-ovarian mass was not done as specimen was already fixed in formalin. 
Table 1: Year of publication, country and operation performed in xanthogranulomatous salpingo-oophoritis.

\begin{tabular}{|c|c|c|c|c|c|c|c|c|c|}
\hline $\begin{array}{l}\text { Ref } \\
\text { No. }\end{array}$ & $\begin{array}{l}\text { Country \& year } \\
\text { of publication }\end{array}$ & Age & $\begin{array}{l}\text { Operation } \\
\text { performed }\end{array}$ & NOC & $\begin{array}{l}\text { Ref } \\
\text { No. }\end{array}$ & $\begin{array}{l}\text { Country } \& \text { year } \\
\text { of publication }\end{array}$ & Age & $\begin{array}{l}\text { Operation } \\
\text { performed }\end{array}$ & NOC \\
\hline 3 & USA, 1976 & 26 & THBSO & 1 & 25 & India, 2014 & 32 & Left SO & 1 \\
\hline 4 & USA, 1977 & 24 & Right SO & 1 & \multirow[b]{2}{*}{26} & \multirow[b]{2}{*}{ India, 2014} & 30 & THBSO & \multirow[b]{2}{*}{2} \\
\hline 6 & USA, 1984 & 26 & THBSO & 1 & & & 31 & $\begin{array}{l}\text { THBSO, } \\
\text { colectomy }\end{array}$ & \\
\hline 7 & India, 1995 & 25 & Ooph. & 1 & 27 & India, 2015 & 2 & Right SO & 1 \\
\hline 8 & Tunisia,1999 & 34 & THBSO & 1 & 28 & USA, 2015 & 45 & Left SO & 1 \\
\hline 9 & India, 1999 & 25 & THBSO & 1 & \multirow{3}{*}{29} & \multirow{3}{*}{ Singapore, 2016} & 36 & Left SO & \multirow{3}{*}{3} \\
\hline 1 & USA, 2001 & 47 & THBSO & 1 & & & 45 & THBSO & \\
\hline 10 & Korea, 2001 & 48 & THBSO & 1 & & & 48 & THBSO & \\
\hline 11 & India, 2003 & 42 & Left SO & 1 & 30 & India, 2016 & 45 & THBSO & 1 \\
\hline 12 & India, 2007 & 18 & Right SO & 1 & 31 & India, 2016 & 44 & THBSO & 1 \\
\hline 13 & Europe, 2007 & 84 & THBSO & 1 & 32 & Pakistan, 2017 & 47 & THBSO & 1 \\
\hline 14 & India, 2009 & 25 & THBSO & 1 & 33 & India, 2017 & 14 & Right SO & 1 \\
\hline 15 & India, 2010 & 42 & THBSO & 1 & \multirow{2}{*}{34} & \multirow{2}{*}{ India, 2017} & 17 & $\begin{array}{l}\text { Pelvic mass with } \\
\text { B/L SO }\end{array}$ & \multirow[t]{2}{*}{2} \\
\hline 16 & India, 2011 & 28 & Bilateral SO & 1 & & & 38 & Left SO & \\
\hline 17 & China, 2011 & 32 & THBSO & 1 & \multirow{2}{*}{35} & \multirow{2}{*}{ India, 2017} & 21 & Left SO & \multirow[b]{2}{*}{2} \\
\hline 18 & India, 2012 & 35 & THBSO & 1 & & & 43 & THBSO & \\
\hline 2 & India, 2012 & 45 & THBSO & 1 & 36 & India, 2017 & 20 & Right Ooph. & 1 \\
\hline 19 & Sri Lanka, 2012 & 34 & THBSO & 1 & 37 & India, 2018 & 24 & Right SO & 1 \\
\hline 20 & India, 2013 & 61 & THBSO & 1 & \multirow{3}{*}{38} & \multirow{3}{*}{ India, 2018} & 17 & $\begin{array}{l}\text { Partial } \\
\text { oophorectomy }\end{array}$ & \multirow{3}{*}{3} \\
\hline 21 & India, 2013 & 61 & THBSO & 1 & & & 24 & $\begin{array}{l}\text { Ovarian } \\
\text { cystectomy }\end{array}$ & \\
\hline 22 & India, 2013 & 28 & $\begin{array}{l}\text { Ovarian } \\
\text { cystectomy }\end{array}$ & 1 & & & 25 & $\begin{array}{l}\text { Partial ooph.\& } \\
\text { appendectomy }\end{array}$ & \\
\hline 23 & India, 2013 & 18 & Right SO & 1 & 39 & India, 2019 & 60 & $\begin{array}{l}\text { THBSO with } \\
\text { omental }\end{array}$ & 1 \\
\hline 24 & India, 2014 & 40 & THBSO & 1 & 40 & India, 2019 & 35 & THBSO & 1 \\
\hline
\end{tabular}

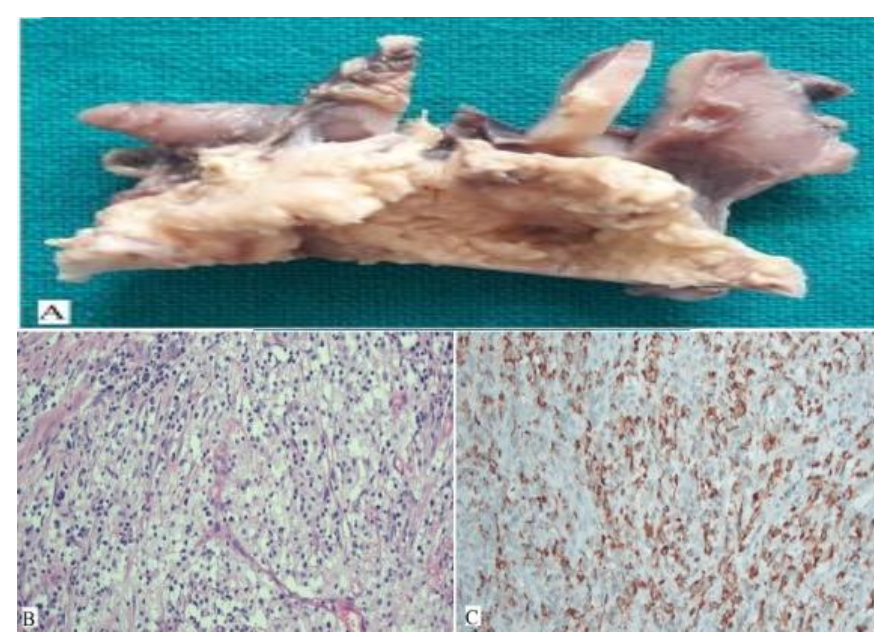

Figure 1: (A) Cut section of tubo-ovarian mass shows yellowish necrotic appearance and attached fallopian tube, (B) histology shows diffuse proliferation of foamy histiocytes and inflammatory cells. (H\&E 400), (C) shows CD 68 cytoplasmic positivity in foamy macrophages (IHC).

\section{DISCUSSION}

The first case of xanthogranulomatous salpingooophoritis was described in 1976, since then only 46 cases of this entity were published in literature..$^{1-4,6-40}$ The age, name of country, year of publication and treatment given in these 46 cases is shown in (Table 1). In the 46 published reports 12 cases are from developed countries; which comprised of 5 cases from USA, 3 from Singapore and one case each from Korea, Europe, China, and Tunisia. ${ }^{1,3,4,6,8,10,13,17,28,29}$ Out of 34 cases reported from developing countries, 32 are described in Indian literature and one case each is documented from Pakistan and Sri Lanka. ${ }^{2,7,9,11,12,14-16,18-20-27,30,31-40}$ The age range of these cases varied from 2-84 years and the most frequent sign and symptoms were lower abdominal or suprapubic pain, fever, menorrhagia, or vaginal bleeding and adnexal tenderness and a pelvic mass. ${ }^{1-4,6-40}$ The risk factors for xanthogranulomatous salpingo-oophoritis is pelvic inflammatory disease, endometriosis, IUCD, antibiotic treatment and cervical stenosis. ${ }^{1-4,6,7,10,11,13-15,18,29,32,38}$ The gross examination of the affected ovary may show replacement by a well circumscribed, solid, yellowish, lobulated mass along with cystic change. ${ }^{1,2,16-18}$ 
Microscopically, it is characterized by a massive infiltration by lipid laden histiocytes known as Xanthoma cells and mixed with inflammatory infiltrates of the affected tissues. ${ }^{1,2,16,18}$ Immunohistochemical stains CD68, CD3 and CD20 are helpful in establishing the diagnosis. Although pathogenesis of vacuolated macrophages is not clear, many authors believe it to be a secondary degenerative change representing the accumulation of different substances ingested by histiocytes. The proposed causes of vacuolated macrophages are abnormality in lipid metabolism and ineffective clearance of bacteria by phagocytes. ${ }^{1,2}$ Bleeding and obstruction may predispose to infection, producing tissue necrosis followed by the release of cholesterol and other lipids that is phagocytized by macrophages. ${ }^{1}$ In several reports' bacteria including Actinomyces, Staphylococcus aureus, Streptococcus faecalis, Escherichia coli were grown on culture of tuboovarian abscess. It is thought that the colonization of the IUCD in the endometrial cavity is followed by the shedding of bacteria through the lumen of the fallopian tube. ${ }^{2}$ Alternatively ovarian surface is exposed to bacteria at the time of ovulation, the corpus luteum becomes infected, producing an ovarian abscess. Oophorectomy is the most recommended treatment for xanthogranulomatous oophoritis, however intraoperatively these lesions usually mimic ovarian malignancy and hence call for the tendency towards extensive surgery, including total hysterectomy. In 26 out of 46 reported cases hysterectomy with bilateral salpingooophorectomy was performed. . $^{1-3,6,8-10,13-15,17-21,24,26,29-}$ $32,35,39,40$

The differential diagnosis of xanthogranulomatous salpingitis and oophoritis includes both non-neoplastic and neoplastic conditions. The non-neoplastic conditions are mainly infections such as tuberculosis and fungal infections and malakoplakia that need to be ruled out by cultural studies and special stains such as periodic acid Schiff stain, gram stain and acid-fast stains.

\section{CONCLUSION}

High prevalence of xanthogranulomatous salpingooophoritis is seen in Indian women. Frozen section study of tubo-ovarian mass may be useful in establishing accurate diagnosis, so that unnecessary hysterectomy can be avoided.

\section{ACKNOWLEDGMENTS}

Dr. Sonali Lanjewar, Department of Pathology, Methodist University Hospital, University of Tennessee, Health Science Center, Memphis, USA.

Funding: No funding sources Conflict of interest: None declared Ethical approval: Not required

\section{REFERENCES}

1. Gray Y, Libbey NP. Xanthogranulomatous salpingitis and oophoritis: a case report and review of the literature. Arch Pathol Lab Med. 2001;125:260-3.

2. Kalloli M, Bafna UD, Mukherjee G, Devi UK, Gurubasavangouda, Rathod PS. A rare xanthogranulomatous oophoritis presenting as ovarian cancer. Online J Health Allied Scs. 2012;11:11.

3. Kunakemakorn P, Ontai H. Pelvic inflammatory pseudotumor: a case report. Am J Obstet Gynecol. 1976;26:286-7.

4. Wlodarski FM, Trainer TD. Granulomatous oophoritis and salpingitis associated with Crohn's disease of the appendix. Am J Obstet Gynecol. 1975;2013:527-8.

5. Barua R, Kirkland JA, Petrucco OM. Xanthogranulomatous endometritis: Case report. Pathology. 1978;10:161-4.

6. Pace EH, Voet RL, Melancon JT. Xanthogranulomatous oophoritis: an inflammatory pseudotumor of the ovary. Int J Gynecol Pathol. 1984;3:398-402.

7. Singh UR, Revathi G, Gita R. Xanthogranulomatous oophoritis: an unusual complication of typhoid. J Obstet Gynaecol. 1995;21:433-6.

8. Chechia A, Bahri N, Felah R, Khaireddine A, Sakouhi M, Zakhama A. Tubo-ovarian xanthogranulomatous inflammation, report of a case. Tunis Med. 1999;77:593-6.

9. Naik M, Madiwale C, Vaideeswar P. Xanthogranulomatous oophoritis- a case report. Indian J Pathol Microbiol.1999;42:89-91.

10. Seung EJ, Jae ML, Kyo-Young L, Ku TH, Seong TH. Xanthogranulomatous Oophoritis MR Imaging Findings with Pathologic Correlation. American Journal of Roentgenology. 2002;178(3):749-51.

11. Punia RS, Aggarwal R, Amanjit, Harsh Mohan. Xanthogranulomatous oophoritis and salpingitis: late sequelae of inadequately treated staphylococcal PID. Indian J Pathol Microbiol. 2003;46:80-1.

12. Hemalatha AL, Rao S, Deepak KB, Gayathri MN, Manjunath BS, Rathna S. Xanthogranulomatous salpingo-oophoritis: a rare entity at an exceptional site. Indian J Pathol Microbiol. 2007;50:607-9.

13. Altanis S, Raweily E, Katesmark M. Xanthogranulomatous endometritis and oophoritis secondary to diverticulitis. A rare cause of postmenopausal bleeding. J Obstet Gynaecol. 2007;27:746-7.

14. Singh N, Dadhwal V, Sharma KA, Mittal. Xanthogranulomatous inflammation: a rare cause of premature ovarian failure. Arch Gynecol Obstet. 2009;279:729-31.

15. Shukla S, Pujani M, Singh SK, Pujani M. Xanthogranulomatous oophoritis associated with primary infertility and endometriosis. Indian J Pathol Microbiol. 2010;53:197-8. 
16. Mahesh KU, Potekar RM, Yelikar BR, Pande P. Xanthogranulomatous oophoritis-masquerading as ovarian neoplasm. Asian $\mathrm{J}$ Pharm and Sci. 2012;2:308-9.

17. Zhang XS, Dong HY, Zhang LL, Desouki MM, Zhao C. Xanthogranulomatous inflammation of the female genital tract: report of three cases. J Cancer. 2012;3:100-6.

18. Raj JA, Jagadeesha M, Naveen S, Ramachandra U. Xanthogranulomatous oophoritis: pathologic findings with clinical correlation. J Indian Med Assoc. 2012;110:653-4.

19. Abeysundara PK, Padumadasa GS, Tissera WG, Wijesinghe PS. Xanthogranulomatous salpingitis and oophoritis associated with endometriosis and uterine leiomyoma presenting as intestinal obstruction. J Obstet Gynaecol Res. 2012;38:1115-7.

20. Shashikala K, Sharmila PS, Sushma T A, Francis P. Ovarian haemangioma with synchronous xanthogranulomatous inflammation - a rare pathological finding. Int $\mathbf{J}$ Health Sci Res. 2013;3:116-9.

21. Karigoudar MH, Kushtagi AV, Karigoudar RM, Sirasagi A. Xanthogranulomatous oophoritis - A rare inflammatory lesion. J Krishna Inst Med Sci Univ. 2013;2:111-5.

22. Singh N, Tripathi R, Mala YM, Arora S. Xanthomatous oophoritis following uterine artery embolisation: Successful conservative surgical management with favourable outcome. BMJ Case Rep. 2013;2013:bcr2013010184.

23. Shilpa D, Sulhyan K, Sachin B, Gosavi A, Ramteerthkar N. Xanthogranulomatous oophoritis: Case report. Indian J Basic Appl Med Res. 2013;7:745-9.

24. Bindu SM, Mahajan MS. Xanthogranulomatous oophoritis: A case report with review of literature. Int J Health Allied Sci. 2014;3:187-9.

25. Kishor HS, Rajshri PD, Dravid NV. Xanthogranulomatous oophoritis mimicking as an ovarian neoplasm. J Case Rep. 2014;4:100-3.

26. Gupta N, Gupta C. Xanthogranulomatous oophoritis masquerading as ovarian neoplasm: report of two cases. Annal Pathol Lab Med. 2015:2:C24-7.

27. Tanwar H, Joshi A, Wagaskar V, Kini S, Bachhav M. Xanthogranulomatous Salpingooophoritis: the youngest documented case report. Case Rep Obstet Gynecol. 2015; 2015:237250.

28. Son J, Raetskaya-Solntseva O, Tirman PA, Water GS, Kelly MG. Xanthogranulomatous oophoritis presenting as an adenexal mass and bowel obstruction, a case report. J Reprod Med. 2015;60:273-6.

29. Pang SY, Aggarwal IM, Lim YK. Xanthogranulomatous Salpingo-Oophoritis mimicking an ovarian malignancy, a series of 3 cases and review of literature. Obstet Gynecol Int J. 2016;5:00162.

30. Tripathy S, Santhamani PM. Xanthogranulomatous oophoritis: a rare chronic inflammatory nonneoplastic ovarian pseudotumor. Int $\mathrm{J}$ Reprod Contracept Obstet Gynecol. 2016;5:3616-8.

31. Sharma S, Phadnis P, Kudva R, Valiathan M, Shetty J. Xanthogranulomatous salpingooophoritis presenting as tubo-ovarian mass- a case report with brief review of literature. Int $\mathbf{J}$ Health Sci Res. 2016;6:316-9.

32. Khan B, Aziz AB, Ahmed R. Case of Xanthogranulomatous Oophritis. J Ayub Med Coll Abbottabad. 2017;29:162-4.

33. Anant M, Sinha K, Agarwal M, Sinha HH, Bhadani P. Serous cystadenoma of ovary with xanthogranulomatous oophoritis: combination of benign ovarian tumour with chronic inflammatory non-neoplastic pseudo-tumour-a rarity. Int J Reprod Contracept Obstet Gynecol. 2017;6:1682-5.

34. Jindal D, Mankad MH, Dave PS, Kamath AA. Xanthogranulomatous oophoritis presenting as a pseudotumor of the ovary: a clinical dilemma. Int $\mathbf{J}$ Reprod Contracept Obstet Gynecol. 2017;6:2098100.

35. Rathore R, Chauhan S, Mendiratta S, Sharma R, Nain M, Sarin N. Xantogranulomatous Salpingo Oophritis, lessons learnt: report of two cases with unusual presentation. J Family Reprod Health. 2017;11:174-8.

36. Bhatnagar K, Narang V, Garg B, Sood N. Xanthogranulomatous Oophoritis: a rare case report. Iran J Pathol. 2018;13:372-6.

37. Rawal G, Zaheer S, Dhawan I. Xanthogranulomatous Oophoritis mimicking an ovarian neoplasm: a rare case report. J Midlife Health. 2018;9:41-3.

38. Jaiman S, Gundabattula SR, Dasari S, Pochiraju M. Atypical xanthogranulomatous inflammation of the female genitaltract. Eur J Obstet Gynecol. 2018;222:186-7.

39. Kaur B, Verma M, Gupta S. Xanthogranulomatous Salpingo-Oophoritis masquerading as an ovarian neoplasm: a case report. Indian J Gynecol Oncolog. 2019; $17: 23$

40. Besina S, Naheena B. XanthogranulomatousOophritis masquerading as ovarian neoplasm: a case report. Journal of Medical Sciences. 2019;22:71-4.

Cite this article as: Patel KA, Chothani KP, Patel B, Lanjewar DN. Xanthogranulomatous salpingooophoritis: a case report and review of literature. Int J Reprod Contracept Obstet Gynecol 2020;9:4316-9. 